\title{
Albright's Hereditary Osteodystrophy
}

National Cancer Institute

\section{Source}

National Cancer Institute. Albright's Hereditary Osteodystrophy. NCI Thesaurus. Code C118434.

A rare, autosomal dominant syndrome caused by mutations in the GNAS gene. It is characterized by the presence of short stature, obesity, round face, brachydactyly, subcutaneous ossifications, and pseudohypoparathtyroidism. 